\title{
Bioconversion of Food Waste by Black Soldier Fly, Hermetia illucens larvae (Diptera: Stratiomyidae L.) for Alternative Animal Feed Stock
}

\author{
Ucu Julita $^{1}$, Siti Sawitri Fatimah ${ }^{2}$, Yani Suryani ${ }^{3}$, Ida Kinasih ${ }^{4}$, Lulu Lusianti Fitri ${ }^{5}$, Agus \\ Dana Permana ${ }^{6}$ \\ \{ucujulita@uinsgd.ac.id ${ }^{1}$, witrisisafa@gmail.com ${ }^{2}$, \\ yanisuryani@uinsgd.ac.id ${ }^{3}$,idakinasih@uinsgd.ac.id ${ }^{4}$, lfitri@sith.ac.id ${ }^{5}$, \\ agus@sith.itb.ac.id $\left.{ }^{6}\right\}$
}
Biology Departement Faculty of Science and Technology UIN Sunan Gunung Djati, Bandung ${ }^{1-4}$, School of Life Sciences and Technology ${ }^{5}$, Institut Teknologi Bandung ${ }^{6}$

\begin{abstract}
Food waste is potential organic waste as growing media for supporting black soldier fly larval growth. It is rich in nutrients containing carbohydrates, protein and fat. A black soldier fly larva is an insect that has the ability to convert various types of organic waste into biomass that valuable as animal feed. Bioconversion process by larvae can be used as an alternative technology for organic waste management that environmentally friendly and low cost. This study aimed to determine the ability of black soldier larvae in converting organic waste based on larval growth rate, larval mortality rate, waste reduction index (WRI) and digestible feed efficiency (ECD). The research method was carried out on 3-day-old larvae fed with food waste (fruits waste and restaurant waste) with variations in feeding rate : 50,100,150 and $200 \mathrm{mg} / \mathrm{larva} /$ day (wb). All treatment was replicated five times and all samples were measured in dry weight $(\mathrm{mg})$. The results showed that the treatment of restaurant waste $150 \mathrm{mg} /$ larva/day (wb) is the highest larval final weight of $87.55 \mathrm{mg}(\mathrm{db})$, the fastest growth time for 28 days with the lowest mortality rate of 3.99 $\%$, and the highest ECD (21.02\%).
\end{abstract}

Keywords: Bioconversion, Black soldier fly, organic waste, ECD, WRI

\section{Introduction}

Organic waste is the highest contributor to urban waste produced both from domestic waste and non-domestic waste.[1] Based on data from the ministry of environment and forestry (2017), the waste composition in Indonesia consisted of $63.56 \%$ organic waste, $10.442 \%$ paper, $1.7 \%$ glass, $1.45 \%$ plastic/rubber, $9.76 \%$ metal, fabric $0.95 \%$, others $12.16 \%$. The organic waste is dominated by food waste consisting of the kitchen waste, food scraps, vegetable and fruit waste [2]. The kitchen waste especially the food scrap is usually produced from the restaurant's activities including Padang restaurant while fruit waste produced from market waste. These organic wastes are rich in water content as well as organic ingredients in the form of carbohydrates, proteins, and fats [3]. Bioconversion is the conversion of organic materials into 
usable products or energy sources by biological processes or agents, such as certain microorganisms (bacteria, fungi) and insect larvae (Family: Calliphoridae, Muscidae, Stratiomyidae). Black soldier fly is a cosmopolitan insect widely spread in various habitat in the world [4]. Larvae of black soldier fly able to live and develop in a variety of organic media because its have a wide $\mathrm{pH}$ tolerance [5]. Black soldier fly larvae can be used as bioconversion agents that effectively break down organic material most of their life phases act as decomposers (larval phase) [6]. The larvae are able to reduce various types of organic waste up to $35-45 \%$ of the total waste weight [7] and able to decompose up to $68 \%$ of urban waste, $50 \%$ of chicken manure, $39 \%$ of pig manure and $25 \%$ of a mixture of chicken and cattle manure [8]. It is due to several bacteria found in the digestive tract of black sorldier larvae which capable of producing digestive enzymes such as amylase, protease, and lipase to hydrolyze the substrate for then used it as feed [9]. This study aimed to determine the ability of larvae in converting fruits waste and restaurants waste based on the larval growth rate, larval mortality, WRI (waste reduction index) and ECD (digestible feed efficiency).

\section{Materials and Methods}

The research was conducted at the Screen House of the Faculty of Science and Technology UIN Sunan Gunung Djati Bandung. The eggs of black soldier fly were obtained from the Research Institute for Ornamental Fish Culture (BPPBIH) Depok, West Java. The eggs were hatched and raised in chicken feed media for 3 days. The three days old larvae were then given daily feed using fruits waste and restaurants waste with the feeding rate of 50, 100, 150 and 200 $\mathrm{mg} /$ larva/day (wet base/wb) respectively. The total of 100 larvae was used in each treatment with three replications. The tretament was stopped when $50 \%$ of the larvae turned into prepupa. Samples were measured in dry weight $(\mathrm{mg})$ [10]. Observation parameters consisted of larval final weight, growth period, mass balance, the ratio of feed use proportion, waste reduction index (WRI) and digestible feed efficiency (ECD), as well as larval mortality rate.

WRI is a waste reduction index in a certain period of time. The WRI value was determined using the equation:

$$
D=\frac{W-R}{W}
$$

where: $\mathrm{D}=$ percentage of degraded substrate weight, $\mathrm{W}=$ the total amount of dry weight substrate during a time $(\mathrm{t})$ of the experiment, while $\mathrm{R}=$ the residual dry weight during a time ( $\mathrm{t}$ ) of the experiment

$$
W R I=\frac{D}{t} \times 100
$$

ECD is the efficiency of digestible feed that is digested by larvae during the raising period. The digestible feed efficiency was calculated using equations [10] : 


$$
E C D=\frac{B}{(I-F)} \times 100 \%
$$

where: $\mathrm{ECD}=$ digestible feed efficiency, $\mathrm{B}=$ dry weight of the biomass formed $(\mathrm{mg} \mathrm{dw})$, $\mathrm{I}=$ initial weight of substrate $(\mathrm{mg} \mathrm{dw})$, and $\mathrm{F}=$ dry weight of casting (unconsumed food + excreted waste) ( $\mathrm{mg} \mathrm{dw})$.

The mortality rate is the percentage of the number of dead larvae compared to the initial number of larvae which can be determined using the equation:

$$
M=\frac{N}{n} \times 100 \%
$$

Where $\mathrm{M}=$ percentage of dead larvae, $\mathrm{N}=$ total number of dead larvae, and $\mathrm{n}=$ total initial number of larvae.

\section{Results and Discussion}

\subsection{Larval Biomass Growth Rate}

The final larval weight in the two types of feed increased significantly along with the amount of feed supplied. Feeding activity of black soldier fly occurs in the larval period. The nutrient intake by continous feeding in larva stage needed to obtain the optimum energy for supporting its growth. Based on the results in Figure 1. there was a significant increase of larval dry weight in 150 and $200 \mathrm{mg} /$ larva/day (wet base/wb) feed treatment. Whereas in the feed treatment of 50 and $100 \mathrm{mg} /$ larva/day (wb) there was an increase in larval dry weight, but it was not significant compared to the previous treatment.

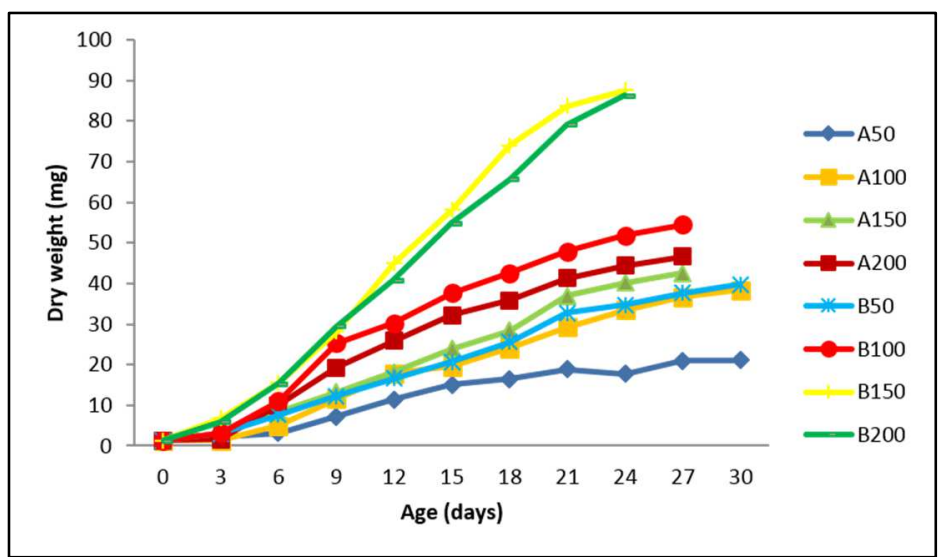

Figure 1. Growth rate of larval biomass and final prepupal weight reared on fruit waste (A) and restaurant waste (B) with different feed rate $(50,100,150$ and $200 \mathrm{mg} /$ larva/day) 
In this study, the feeding rate affect the rate of larval growth, as the increase of feeding rate will accelerate the duration of the larvae to reach the prepupa stage. The larval body weight will increase until entering the prepupa stage. When entering pupa stage, there is no more feeding activity so the weight of prepupa slightly reduced [11]. The previous study demonstrated that food availability can affect the life history of larvae, the more abundant the availability of food, the faster the growth of larvae [12]. Conversely, if there a few food availability, the larval growth will be extended for up to 4 months (Myers et al., 2008). Comparison of the estimated growth of black soldier fly larvae including the final larval weight, the growth period to reach the prepupa phase, and the feeding duration presented in Table 1.

Table 1. Comparison of final larval weight, larval period and feeding duration of black soldier reared on different feeding rate.

\begin{tabular}{cccc}
\hline $\begin{array}{c}\text { Treatment } \\
(\mathbf{w b})\end{array}$ & $\begin{array}{c}\text { Final larval weight } \\
(\mathbf{m g})(\mathbf{d b})\end{array}$ & $\begin{array}{c}\text { Parameter } \\
\text { Larval period (days) }\end{array}$ & $\begin{array}{c}\text { Treatment period } \\
\text { (days) }\end{array}$ \\
\hline A50 & $21.09 \pm 0.54 \mathrm{a}$ & $33.00 \pm 0.00 \mathrm{~d}$ & $30.00 \pm 0.00 \mathrm{~d}$ \\
A100 & $38.31 \pm 0.12 \mathrm{~b}$ & $33.00 \pm 0.00 \mathrm{~d}$ & $30.00 \pm 0.00 \mathrm{~d}$ \\
$\mathbf{A 1 5 0}$ & $42.61 \pm 0.87 \mathrm{c}$ & $31.00 \pm 1.00 \mathrm{c}$ & $28.00 \pm 1.00 \mathrm{c}$ \\
A200 & $46.56 \pm 0.74 \mathrm{~d}$ & $30.00 \pm 0.00 \mathrm{bc}$ & $27.00 \pm 0.00 \mathrm{bc}$ \\
B50 & $3977 \pm 009 \mathrm{~b}$ & $33.00 \pm 0.00 \mathrm{~d}$ & $30.00 \pm 0.00 \mathrm{~d}$ \\
B100 & $54.55 \pm 1.03 \mathrm{e}$ & $30.00 \pm 0.00 \mathrm{bc}$ & $27.00 \pm 0.00 \mathrm{bc}$ \\
B150 & $87.55 \pm 0.49 \mathrm{f}$ & $28.00 \pm 1.00 \mathrm{a}$ & $25.00 \pm 1.00 \mathrm{a}$ \\
B200 & $86.38 \pm 0.57 \mathrm{f}$ & $29.00 \pm 0.00 \mathrm{ab}$ & $26.00 \pm 0.00 \mathrm{ab}$ \\
\hline
\end{tabular}

The average values followed by the same letter in the same column are not significantly different by the ANOVA analysis followed by the Duncan test $(P<0.05)$.

The treatment of restaurant waste with $150 \mathrm{mg} / \mathrm{larva} /$ day (wet base/wb) feeding rate has the highest final larval weight $(87.55 \mathrm{mg}$, dry base/db) and 28 days growth period. The lowest final larval weight was on fruits waste with with $50 \mathrm{mg} / \mathrm{larva} /$ day $(\mathrm{wb})$ feeding rate $(21.09 \mathrm{mg}$, dry base/db) and 33 days of larval period (Table. 1). This study indicated that the larvae fed with restaurants waste produced higher final larval weight and faster growth rate compared with another treatment. Nutrient content in rearing substrate greatly influences the larval growth. Based on the proximate analysis, protein content on the restaurants waste $(31.67 \%)$ was higher than fruits waste $(6.71 \%)$. Protein is needed for larval growth and high protein content in feed can produce high biomass of larvae [13] [14]. Fruit waste containing low protein affects the development time of larvae to be longer. In previous studies, black soldier larvae reared on gainesville feed with low protein diet (7\%) had a longer developmental time than those treated with higher protein diet $(35 \%)$ and the fastest larval development time was on optimum protein diet treatment (21\%) [15]. 
The Result on comparison of feed conversion by black soldier fly larvae presented in Figure 2

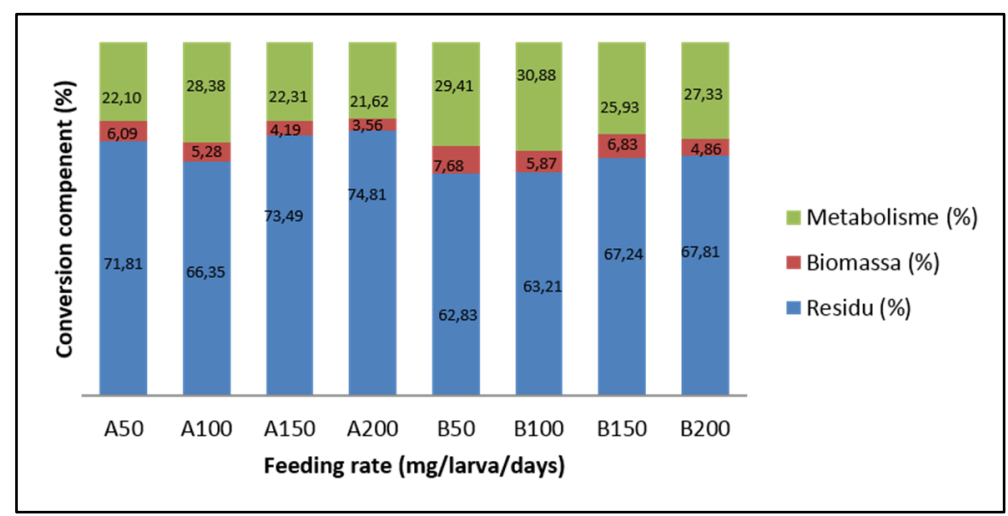

Figure 2. The percentage of organic substrate conversion by black soldier fly larvae

Mass balance analysis is carried out to find out the total feed supplied during the study which was converted by black soldier larvae for metabolic processes, biomass, and residues from the treatment of fruit and restaurant waste. While the relative proportions were analyzed to compare between the amount of different feeds used during the study with the percentage of feed used for metabolism, biomass and residual feed of each treatment. Based on the relative proportion of feed data in Figure 2, the amount of feed from each treatment was used by H. illucens larvae with different percentages. Feeds that are converted for metabolic processes range from 21.62$30.88 \%$ of feed converted into biomass ranging from $3.56-7.68 \%$ and feed residues range from $62.83-74.81 \%$.

Fruit waste treatment with $200 \mathrm{mg} / \mathrm{larva} / \mathrm{day}(\mathrm{wb})$ was the highest feed conversion (46.56 $\mathrm{mg} /$ larva of biomass $(\mathrm{db})$ or $3.56 \%$ of total feed and biomass and the formation rate of 1.41 $\mathrm{mg} /$ day. Whereas, restaurants waste with $150 \mathrm{mg} / \mathrm{larva} / \mathrm{day}(\mathrm{wb})$ generated the highest feed conversion with of larvae biomass formation $(87.55 \mathrm{mg} / \mathrm{larva}(\mathrm{db}))$ or $6.83 \%$ of total feed and of $3.12 \mathrm{mg} /$ day biomass formation rate. The results indicate that restaurant waste generated higher biomass. This is due to higher protein content in the reataurant waste compared to the protein content of fruit wastes. In this study, restaurant waste was a better growth medium for black soldier fly larvae compared with fruits waste. The restaurant waste contains more variation of feed ingredients than fruits waste, so the nutritional needs for the survival of black soldier larvae more fulfilled [16].

Feeding $200 \mathrm{mg} / \mathrm{larva} / \mathrm{day}(\mathrm{wb})$ of the two types of feed resulted in the highest feed conversion on the residual formation. It is presumed due to excessive feeding or overfeeding that result in a reduction of feeding efficiency. The results of feed conversion produced two products, namely, larval biomass and feed residue. The Larval biomass formed can be used as an alternative animal and aquaculture feed which is rich in protein, while the formed food residue has the potential to be used as a good compost fertilizer [7] [8]. The ability of black soldier fly larvae in converting fruits waste and restaurant waste due to digestive enzymes such 
as amylase, protease, and lipase that hydrolyze the substrate used as feed [9]. This is also related to the bacteria found in its digestive tract, Micrococcus sp, Streptococcus sp, Bacillus $s p$ and Aerobacter aerogens which helps to digest food [17].

Furthermore, to determine the ability of larvae in converting fruits waste and restaurant waste, the value of waste reduction index (WRI) and digestible feed conversion (ECD) were measured (Table 3.).

Table 3. The waste reduction index/WRI and Efficiency of Conversion Digested feed/ECD)

\begin{tabular}{ccc}
\hline \multirow{2}{*}{ Treatment } & \multicolumn{2}{c}{ Parameter } \\
\hline W50 & $0.94 \pm 0.01 \mathrm{a}$ & $20.61 \pm 0.16 \mathrm{~b}$ \\
A100 & $1.12 \pm 0.00 \mathrm{~b}$ & $15.68 \pm 0.03 \mathrm{a}$ \\
A150 & $0.95 \pm 0.01 \mathrm{a}$ & $15.91 \pm 0.70 \mathrm{a}$ \\
A200 & $0.93 \pm 0.00 \mathrm{a}$ & $14.15 \pm 0.26 \mathrm{a}$ \\
B50 & $1.24 \pm 0.01 \mathrm{c}$ & $20.86 \pm 0.34 \mathrm{~b}$ \\
B100 & $1.36 \pm 0.01 \mathrm{e}$ & $16.06 \pm 071 \mathrm{a}$ \\
B150 & $1.31 \pm 0.10 \mathrm{~d}$ & $21.02 \pm 1.41 \mathrm{~b}$ \\
B200 & $1.24 \pm 0.02 \mathrm{c}$ & $15.22 \pm 1.51 \mathrm{a}$ \\
\hline
\end{tabular}

The average values followed by the same letter in the same column are not significantly different by the ANOVA analysis followed by the Duncan test $(\mathrm{P}<0.05)$.

The treatment of $100 \mathrm{mg} /$ larva/day feeding rate was resulted the highest WRI both on fruits waste and restaurant waste. While the treatment with $200 \mathrm{mg} / \mathrm{larva} /$ day feeding rate was the lowest WRI value. This is appropriate to the previous study, in which the highest waste reduction index value was on with $100 \mathrm{mg} /$ larva/day (wb) feeding rate of chicken feed [10]. Based on the statistical analysis, restaurants waste with $100 \mathrm{mg} / \mathrm{larva} /$ day $(\mathrm{wb})$ had the highest WRI value compared to the other treatments (1.36). A high waste reduction index value indicates a good reduction efficiency [10].

The results obtained showed that the larvae reduce Padang restaurants food waste easier than fruit waste. This might be due to the water content in the feed. Fruit waste has a higher water content than Padang restaurants food waste. The media with high water content caused the difficulty of larvae in reducing feed [18].

Based on the ECD value, Padang restaurants food waste have the highest average value compared to fruit waste. The results of the statistical analysis showed that ECD values were significantly different, where treatment B150 had the highest ECD value of $21.02 \%$, but the results were not significantly different from those of B50 and A50. While A200 has the lowest ECD values of $14.15 \%$, but it is not significantly different from the treatment of A100, A150, B100, and B200.

These results indicate that the process of consuming Padang restaurants food waste is more easily digested by larvae and converted into higher larval biomass compared to consuming the fruit waste. The low ECD value of insect larval growth is related to the quality of the available feed. Poor quality of feed will give a lower ECD value [1]. 
Fruit waste has a crude fiber content of $9.00 \%$ which is greater than its protein content of $6.71 \%$. This will reduce the protein digestibility in the body of the larvae. According to Wahyu (2004) [19], feed with high crude fiber will produce more excreta, because undigested crude fibers can carry digestible food substances from other food ingredients to be excreted, causing reduced input of digestible proteins. Higher protein content in feed will produce higher biomass [13].

\subsection{Mortality Rate}

The result in this study revealed that $H$. illucens larval mortality rate was between 3.99$18.67 \%$. The lowest mortality rate was in treatment B150 (Padang restaurants food waste 150 $\mathrm{mg} / \mathrm{larva} /$ day) of $3.99 \%$ and the highest was in the treatment A50 of $18.67 \%$ (Fruit waste food) (Figure 4).

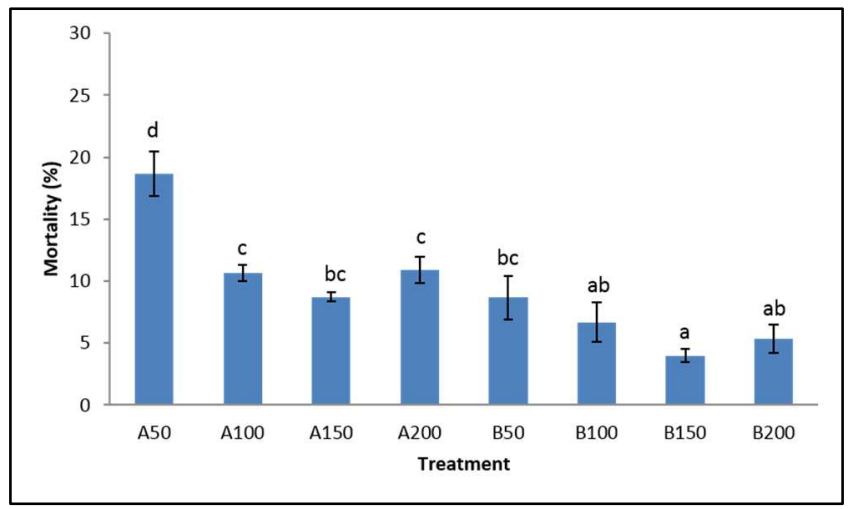

Figure 3. The mortality of $H$. illucens Larvae. The average values of the same letter are not significantly different by ANOVA analysis followed by the Duncan test $(\mathrm{P}<0.05)$.

Based on Figure 3. it showed that the larvae fed with Padang restaurants food waste resulted in a lower mortality rate compared to larvae fed with fruit waste. This is influenced by the quality of feed, especially the protein content. The Padang restaurants food waste has higher protein content compared to the fruit waste. Feed with low protein content has been associated with a high mortality rate, because larvae fed with low protein content have less abitility in converting nitrogen intake to body nitrogen [20]. Nitrogen acts as a body thermoregulator [21], and plays a role in the body's resistance through the haemolyph system, which affects the level of lysosome activity that affects the immune system 


\section{Conclussion and Recommendations}

Feeding Padang restaurants food waste as many as $100 \mathrm{mg} /$ larva day (wb) resulted in the highest WRI value of 1.36 , treatment of $150 \mathrm{mg} / \mathrm{larva} /$ day $(\mathrm{wb})$ resulted in the highest ECD value of $21.02 \%$ as well as the highest the final larval weight of $87.55 \mathrm{mg}(\mathrm{db})$, the fastest growth period was 28 with the lowest mortality rate of $3.99 \%$. The amount of Padang restaurants food waste at $150 \mathrm{mg} / \mathrm{larva} /$ day (wb) was the best treatment in converting organic waste.

Proximate testing of $H$. illucens larvae is needed to determine the composition of proteins and fats which can be applied as an alternative feed for livestock as well as the proximate test of feed residues that have the potential as fertilizers.

\section{References}

[1] "Indonesian Ministry of Environment and Forestry," 2017.

[2] K. Diener, S., Zurbrugg, C., Gutierrez, F. R., Nguyen, D. H., Morel, A., Koottatep, T. \& Tockner, "Proceedings of the Waste Safe-2nd International Conference on Solid Waste Management in the Developing Countries," Waste and Biomass Valorization, vol. 2, no. 4, pp. 357-363, 2011, doi: 10.1007/s12649-011-9079-1.

[3] U. Suriawiria, "Mikrobiologi Air dan Dasar-Dasar Pengolahan Buangan Secara Biologis,” PT Alumni, Bandung, pp. 1-7, 2003.

[4] R. Rozkosný, “A Biosystematic Study of the European Stratiomyidae (Diptera)," Vol. 2 - Clitellariinae, Hermediinae, Pachygasterinae Bibliogr., vol. 25, pp. VIII, 431, 1983.

[5] W. Mangunwardoyo, A. Aulia, and S. Hem, "Penggunaan Bungkil Inti Kelapa Sawit Hasil Biokonversi sebagai Substrat Pertumbuhan Larva Hermetia illucens L (Maggot)," J. Biota, vol. 16, no. 2, pp. 166-172, 2011, doi: 10.24002/biota.v16i2.95.

[6] M. R. Fahmi, S. Hem, and I. W. Subamia, "Potensi Maggot untuk Peningkatan Pertumbuhan dan Status Kesehatan Ikan,” J. Ris. Akuakultur, vol. 4, no. 2, pp. 221232, 2009.

[7] G. L. N. D. Craig Sheppard, "A VALUE ADDED MANURE MANAGEMENT SYSTEM USING THE BLACK SOLDIER FLY,” Osterr. Zeitschrift fur Polit., vol. 37, no. 4, pp. 401-417, 1994.

[8] K. Diener, S., Studt Solano, N. M., Roa Gutiérrez, F., Zurbrügg, C. \&amp; Tockner, "Biological Treatment Of Municipal Organic Waste Using Black Soldier Fly Larvae. Waste Biomass Valorization," 2003.

[9] D. H. Ateng Supriyatna, Dea Amalia, Ayu Agustini Jauhari, “AKTIVITAS ENZIM AMILASE, LIPASE, DAN PROTEASE DARI LARVA,” Pakistan J. Biol. Sci., vol. Ix No 2, no. 2, pp. 246-252, 2015, doi: 10.3923/pjbs.2004.246.252.

[10] S. Diener, C. Zurbrügg, and K. Tockner, "Conversion of organic material by black soldier fly larvae: Establishing optimal feeding rates," Waste Manag. Res., vol. 27, no. 6, pp. 603-610, 2009, doi: 10.1177/0734242X09103838.

[11] R. RACHMAWATI, D. BUCHORI, P. HIDAYAT, S. HEM, and M. R. FAHMI, "Perkembangan dan Kandungan Nutrisi Larva Hermetia illucens (Linnaeus) (Diptera: 
Stratiomyidae) pada Bungkil Kelapa Sawit,” J. Entomol. Indones., vol. 7, no. 1, p. 28, 2015, doi: 10.5994/jei.7.1.28.

[12] H. M. Myers, J. K. Tomberlin, B. D. Lambert, and D. Kattes, "Development of Black Soldier Fly (Diptera: Stratiomyidae) Larvae Fed Dairy Manure,” Environ. Entomol., vol. 37, no. 1, pp. 11-15, 2008, doi: 10.1093/ee/37.1.11.

[13] S. Hem, S. Toure, C. Sagbla, and M. Legendre, "Bioconversion of palm kernel meal for aquaculture: Experiences from the forest region (Republic of Guinea)," African J. Biotechnol., vol. 7, no. 8, pp. 1192-1198, 2008, doi: 10.4314/ajb.v7i8.58644.

[14] L. Sri, B. Trisnowati, Ambarningrum, and P. Hery, "Tabel Hidup Spodoptera litura Fabr. dengan Pemberian Pakan Buatan yang Berbedae,” J. Sain Vet., vol. 31, no. 2, pp. 166-167, 2013.

[15] T. T. X. Nguyen, J. K. Tomberlin, and S. Vanlaerhoven, "Influence of Resources on Hermetia illucens. (Diptera: Stratiomyidae) Larval Development," J. Med. Entomol., vol. 50, no. 4, pp. 898-906, 2013, doi: 10.1603/me12260.

[16] J. PALAYUKAN, "KONSUMSI DAN DAYA CERNA PROTEIN KASAR DAN SERAT KASAR PAKAN KOMPLIT YANG MENGANDUNG KADAR PULP KAKAO YANG BERBEDA PADA KAMBING PERANAKAN ETAWA," Skripsi. Univ. Hasanuddin (2017)., vol. 102, no. 4, pp. 24-25, 2017, doi: 10.1002/ejsp.2570.

[17] O. A. L. A. 0. 0. O. A.D. BANJO, "BACTERIA ASSOCIATED WITH HERMETIA ILLUCENS. (LINAEUS) DIPTERA: STRATIOMYIDAE,” vol. Vol 07, no. Issue 3, p. Page No.(351-354), 2005.

[18] A. P. H. T. B. M. P. ARIF RAHMAN HAKIM, "PRODUKSI BAHAN PAKAN IKAN DARI LARVA Hermetia illucens BERBASIS LIMBAH INDUSTRI PENGOLAHAN IKAN DAN KAJIAN KEEKONOMIANNYA,” Tesis Univ. Gadjah Mada, 2017.

[19] P. L. Kwang, "The interactive effects of protein quality and macronutrient imbalance on nutrient balancing in an insect herbivore," J. Exp. Biol., vol. 210, no. 18, pp. 32363244, 2007, doi: 10.1242/jeb.008060.

[20] S. C. Cotter, S. J. Simpson, D. Raubenheimer, and K. Wilson, "Macronutrient balance mediates trade-offs between immune function and life history traits," Funct. Ecol., vol. 25, no. 1, pp. 186-198, 2011, doi: 10.1111/j.1365-2435.2010.01766.x.

[21] R. D. Larry Newton, Craig Sheppard, Wes D, Watson, Gary Burtle, "USING THE BLACK SOLDIER FLY, Hermetia illucens, AS A VALUE-ADDED TOOL FOR THE MANAGEMENT OF SWINE MANURE," J. Korean Entomol. Appl. Sci., vol. 36, no. 12, p. 17 pp., 2005. 